\title{
Peningkatan Kemampuan Pragmatis Penguasaan Bahasa Inggris Bagi Guru di MTs. Jauharul Ulum Desa Locancang Panarukan Situbondo
}

\author{
Ach. Munawi Husein ${ }^{1)}$, Ratih Kesuma Dewi ${ }^{1)}$ \\ 1) Universitas Abdurachman Saleh Situbondo \\ achmunawihusein@yahoo.com,ratih.kesdewi@gmail.com
}

\begin{abstract}
ABSTRAK: Era Globalisasi, pentingnya penguasaan Bahasa Inggris bagi guru tidak dapat dielakkkan lagi. Salah satunya adalah kemampuan komunikasi praktis, misalnya memperkenalkan diri secara formal, mempromosikan sekolah, membuka sebuah acara, dan lain sebagainya. Maka, dengan adanya program tersebut merupakan upaya dari peningkatan mutu kualitas sumber daya manusia melalui penguasaan bahasa asing (Bahasa Inggris). Tujuan dari program tersebut adalah untuk meningkatkan kompetensi guru dalam bidang pengusaan Bahasa Inggris khususnya pada keterampilan (skill) kemampuan pragmatis dalam komunikasi dan memberikan pemahaman terhadap guru akan pentingnya Bahasa Inggris pada era globalisasi. Sasaran dari Program ini adalah masyarakat umum yaitu guru-guru di MTs. Jauharul Ulum, Kendit-Situbondo.
\end{abstract}

Kata kunci : Pelatihan, Pragmatis, Peningkatan Bahasa Inggris, Guru

ABSTRACT: The Era of Globalization, the importance of mastering English for teachers cannot be learned anymore. One of them is practical communication skills, such as formally introducing oneself, promoting schools, opening an event, and so on. Thus, the existence of the program is an effort to improve the quality of human resources through mastery of foreign languages (English). The aim of the program is to improve teacher competency in the field of English language teaching, especially in pragmatic skills in communication and provide understanding of the importance of English in the era of globalization. The target of this program is the general public, namely teachers at MTs. Jauharul Ulum, Kendit - Situbondo.

Keywords: Training, Pragmatic, English Language Improvement, Teacher

\section{PENDAHULUAN}

Pada hakikatnya, belajar bahasa adalah belajar berkomunikasi. Oleh karena itu, pembelajaran bahasa di sekolah diarahkan untuk meningkatkan keampuan siswa dalam berkomunikasi, baik secara lisan maupun tulisan. Bahasa sebagai sarana komunikasi digunakan dalam bermacam-macam fungsi dan disajikan dalam konteks yang bermakna, tidak dalam bentuk kalimat-kalimat lepas. Target utama dalam melakukan komunikasi lisan sesungguhnya adalah bagaimana penutur mampu memahami budaya para lawan bicaranya.

Bahasa adalah hal yang kompleks, memperlajari sebuah Bahasa berarti juga mempelajari tentang faktor-faktor diluar Bahasa itu sendiri seperti, sosial masyarakat dan budaya. Menurut Yuniseffendri (2015:5) kajian interdisipliner antara bahasa dengan faktor-faktor lain di luar bahasa, juga melahirkan suatu kajian yang dikenal dengan istilah pragmatik. Disiplin ilmu yang satu ini lebih menitik beratkan kajian bahasa dikaitkan dengan konteks penggunaannya. 
Pragmatik adalah studi tentang pemakaian bahasa dalam komunikasi terutama hubungan antara ujaran, dengan konteks dan situasi (Richard, 1987). Untuk melakukan fungsi pragmatik secara baik dan benar, dipercayakan kompetensi komunakatif. Kompetensi komunikatif merupakan media untuk melaksanakan fungsi pragmatik. Menurut Tarigan (1988) Kompetensi komunikatif (KK) merupakan kemampuan untuk menerapkan gramatikaI suatu bahasa dalam membentuk kalimat-kalimat yang benar dan untuk mengetahui kapan, dimana, dan kepada siapa kalimat-kalimat itu diujarkan.

Menurut Saefudin (2013:2) pragmatik merupakan satu-satunya tataran yang turut memperhitungkan manusia sebagai pengguna bahasa. Meskipun memiliki fokus kajian yang serupa dengan semantik, yaitu makna, seperti akan dijelaskan kemudian, makna yang dikaji dalam pragmatik berbeda dengan makna yang dikaji dalam semantik. Saefuddin menambahkan bahwa dalam kajian pragmatik yang paling penting adalah bagaimana Bahasa itu berterima (appropriateness). Oleh karena itu keberterimaan dalam berbahasa seharusnya disadari oleh pembelajar Bahasa sejak dini yang menekankan pada kegiatan sehari-hari, mulai dengan konteks lokal. Termasuk dalam pembelajaran bahasa asing, para pembelajar harus diajarkan untuk menggunakan Bahasa yang dia pelajari, mulai dari situasi kehidupan nyata sehari-hari yang dia alami. (2013:4)

Kompetensi komunikatif lebih menekankan pada fungsi bahasa dalam komunikasi sesungguhnya dari pada menguasai bentuk dan kaidah kebahasaan. Pada prinsipnya KK mencakup dua hal, yaitu (a) pengetahuan tentang kebahasaan dan (b) sosial. Kedua hal itu dijabarkan menjadi empat unsur KK, yaitu kompetensi gramatika, sosiolinguistik, wacana dan strategi.

Kompetensi penguasaan bahasa asing, pada tingkat pragmatik (praktis) atau komunikasi parkatis menjadi sebuah keharusan mengingat globalisasi dan adanya revelusi industry 4.0. Realitasnya, Bahasa Inggris digunakan (meskipun secara pasif) hampir disetiap lini kehidupan, sebagai contoh, penggunaan teknologi informasi sebagaian besar menggunakan manual berbahasa Inggris. Dalam dunia pendidikan, Bahasa Inggris diajarkan mulai tingkat sekolah dasar, sehingga Bahasa Inggris dianggap sangat penting untuk diperkenalkan sedini mungkin kepada peserta didik. Selain itu, pendidik atau guru diharapkan memiliki kemampuan penguasaan Bahasa Asing untuk meningkatkan mutu pendidikan dan sumber daya manusia.

Permasalahan yang muncul adalah rendahnya kemamuan atau kurangnya kesadaran untuk belajar Bahasa Inggris, ditengah-tengah kesibukan sebagai pendidik yang cukup menyita waktu, keadaaan ini diperparah oleh tidak adanya pelatihan atau workshop Bahasa Inggris dalam kurun waktu lima tahun (sejak 2014).

Selain itu rendahnya motif (dorongan) dan minat untuk belajar Bahasa Inggris, hal ini berkaitan dengan keadaan yang telah dipaparkan sebelumnya (yaitu tidak adanya fasilitas pelatihan) dan tidak adanya tujuan yang jelas dalam belajar. Faktor-faktor diatas merupakan hal yang saling berkaitan, sehingga menyebabkan permasalahan yang 
berbelit dan berujung pada gagalnya penguasaan Bahasa Inggris, meski telah dipelajari bertahun-tahun.

\section{METODE PELAKSANAAN}

Subyek dari pari kegiatan ini adalah Guru -guru di MTs. Jauharul Ulum, Kecamatan Kendit, Panarukan, Situbondo yang berjumlah sebanyak 10 orang. Adapun mekanisme pelaksanaan dari kegiatan pelatihan ini terdiri dari a) Perencanaan b) Observasi c) Tindakan d) Evaluasi dan e) refleksi.

\section{Tahap Perencanaan / Persiapan}

- Komunikasi dengan pihak sekolah (diwakili oleh Kepala Sekolah)

- Sosialisasi Program bersama Guru-guru MTs. Jauharul Ulum

- Pemilihan Pemateri dan Narasumber Pemateri adalah orang yang akan memberikan materi pelatihan dan Narasumber adalah praktisi pendidikan yang memiliki kemampuan sesuai bidang yang dibutuhkan

- Penetapan Waktu, tempat dan anggota pelatihan Setelah kesepakatan kerjasama maka mitra menentukan waktu, tempat dan anggota pelatihan

\section{Observasi}

- Observasi singkat tentang kondisi sekolah

- Observasi melalui wawancara dengan beberapa Guru tentang penguasaan Bahasa Inggris dan permasalahan atau kesulitan yang dihadapi. Dari hasil observasi diketahui bahwa 90\% Guru (9 orang) menyatakan bahwa kesulitan yang dihadapi saat belajar adalah tidak adanya penerapan atau penggunaan bahasa Inggris yang telah mereka pelajari.

\section{Tindakan}

- Penyusunan Program Pelatihan

Penyusunan program didasarkan pada hasil observasi lapangan dan permaslaahan yang ada. Hasil analisis kondisi dan permasalahan disusun dalam program pelaksanaan pelatihan Peninngkatan kemampuan pragmatis Bahasa Inggris

\section{Evaluasi}

Kegiatan evaluasi dilakukan, untuk memberikan penilain tentang kegiatan yang telah berlangsung. Nara sumber maupun Guru menilai performa selalama kegiatan berlangsung. Evaluasi dilakukan beberapa menit sebelum kegiatan berakhir. Dengan harapan, evaluasi dapat membverikan input yang positif untuk pertemuan selanjutnya, sehingga kegiatan semakin baik.

\section{Refleksi}

Kegiatan refleksi dilakukan, setelah pertemuan ke -8, untuk mengetahui dan memperbaiki hal-hal yang tidak sesuai atau yang tidak proporsional selama 
kegiatan pelatihan. Rekomendasi secara tertulis telah disusun guna perbaikan dikegiatan mendatang.

\section{PELAKSANAAN KEGIATAN}

Guru-guru diberi pelatihan peningkatan Bahasa Inggris selama 8 kali tatap muka, dengan materi yang fokusnya pada kemampuan komunikasi praktis. Materi yang dibertikan kepada guru diantaranya adalah how to introduce yourself in informal and formal situation (memperkenalkan diri secara formal atau informal), how to introduce friend to someone (memperkenalkan teman) how to answer phone (menerima telfon), promoting (mempromosikan sesuatu), inviting, (mengundang),business meeting (pertemuan bisnis), how to say date, day and time (mengutarakan hari, tanggal dan waktu) dan conversation with purposes (percakapan dengan topic).

Satu kali pertemuan kurang lebih 90 menit, dengan alokasi waktu 30-40 menit penyampain materi dan 50 menit untuk practice and discussion (latihan dan diskusi). Saat latihan guru ruang kelas didesain dengan posisi guru membuat lingkaran, sehingga Semua mendapat kesempatan untuk berlatih.

\section{HASIL DAN PEMBAHASAN}

Kegiatan pertama yang dilakukan adalah Sosialisasi Kegiatan. dalam sosialisasi kegiatan, disampaikan maksud dan tujuan dari kegiatan Dan teknis pelaksanaan. Selain itu, guru diberi kesempatan untuk menyaimpaikan permasalahan dalam kesulitan belajar bahasa Inggris. Selanjutnya adalah penyampaian materi berdasarkan analisis kebutuhan Guru. Guru berlatih sesuai dengan materi yang diberikan dan mencoba menerapkannya langsung setelah sesi penyampaian materi.

Adapun hasil dari Kegiatan peningkatan kemampuan pragmatis Bahasa Inggris bagi Guru di MTs. Jauharul Ulum Desa Locancang, Panarukan-Situbondo telah diperoleh hasil diantaranya:

a. Guru mulai menggunakan Bahasa Inggris minimal di lingkungan kantor (sekolah)

b. Termotivasinya guru-guru MTs. Jauharul Ulum untuk belajar Bahasa Inggris yang dapat dilihat melalui keaktifan dalam mengikuti kegiatan PKM Pelatihan Bahasa Inggris

c. Terpenuhinya sebagian kebutuhan materi Bahasa Inggris untuk mendukung pembelajaran Bahasa Inggris praktis

\section{KESIMPULAN DAN SARAN}

\section{Kesimpulan}

Hasil Kegiatan peningkatan kemampuan pragmatis Bahasa Inggris bagi Guru di MTs. Jauharul Ulum Desa Locancang, Panarukan-Situbondo dapat disimpulkan 
bahwa diperlukan pelatihan Bahasa Inggris yang difokuskan pada penggunaan bahasa komunikasi pragmatis bagi Guru secara berkesinambungan. Kegiatan semacam ini diperlukan agar dapat menjaga motivasi dan minat belajar para Guru. Mengingat salah satu penghambat adalah factor lemahnya minat belajar. Pendampingan dan pelatihan diperlukan Sehingga akhirnya, mereka dapat belajar secara mandiri dan ilmu yang didapat digunakan untuk kemajuan institusi.

\subsection{SARAN}

Adapun saran dalam kegiatan peningkatan kemampuan pragmatis Bahasa Inggris bagi Guru di MTs. Jauharul Ulum adalah sebagai berikut:

1. Diperlukan pendampingan yang lebih lama agar terjadi sikap belajar yang konsisten dan berkelanjutan.

2. Diperlukannya modul atau buku ajar yang sesuai dengan kebutuhan belajar para Guru

3. Diperlukan implementasi kebijakan dari pihak sekolah, untuk membetuk budaya belajar yang konsisten.

\section{DAFTAR PUSTAKA}

Richard. Kemampuan Pragmatis Bahasa Inggris. Online. Diakses dari https://media.neliti.com/media/publications/86197-ID-none.pdf pada 19 Maret 2019

Tarigan. Kemahiran pragmatic berbahasa tentukan persaingan global. Online. Diakses dari www. mediaindonesia.com (edisi tanggal 19 Nov 2016) pada 20 Maret 2019.

Saefuddin. Pendekatan Pragmatik dalam mendukung KemampuanKomunikasi. Online. Diakses dari journal.uinjkt.ac.id/index.php/al-turats/article/view/3694 pada 15 April 2019 
Volume 3, Nomor 1, Maret 2019 